\title{
Mobility styles and car sharing use in Europe: attitudes, behaviours, motives and sustainability
}

\author{
Érika Martins Silva Ramos ${ }^{1 *}$, Cecilia Jakobsson Bergstad ${ }^{1}$, Andrea Chicco ${ }^{2}$ and Marco Diana ${ }^{2}$
}

\begin{abstract}
What are the profiles of both users and non-users of car sharing in European cities regarding their travel patterns and psychological aspects? Two subsamples (1519 users and 3695 non-users of car sharing) participated in a survey, translated into seven languages, with 36 questions regarding attitudes towards car sharing, the environment, political orientation, personal norms, frequency of use of different transport modes and transport mode choice for different travel purposes. Through a hierarchical cluster analysis, five distinct mobility styles were identified, with no a priori restriction of the number of clusters. The mobility styles were further characterised by sociodemographic variables and by the motives for making use of car sharing. This paper discusses the implications of research based decision-making and urban planning in a way that guarantees long-term human and environmental security.
\end{abstract}

Keywords: Car sharing, Transport behaviour, Motives, Attitudes

\section{Introduction}

Many cities have adopted targets to foster more sustainable mobility. The concept of sustainability has gained more and more visibility, especially after the United Nations (UN) launched their Sustainable Development Goals (SDGs) program. The SDGs aim to achieve sustainability through economic growth, social inclusion, environmental sustainability and good governance [55]. Within this perspective, sustainability should be understood holistically, by addressing societal growth without compromising future generations' needs [35].

A part of cities' efforts is to alter transport behaviour to more multimodal alternatives and to promote smart solutions to reduce private car use [18]. Among the proposed solutions for new transport systems is the notion of car sharing.

Car sharing started as small cooperatives of people wishing to share the use of private cars, and later systems were then developed, based on fleets of vehicles that can be rented on an hourly basis and that need to be returned to the same location after use. More

\footnotetext{
* Correspondence: erika.ramos@psy.gu.se

${ }^{1}$ Department of Psychology Box 500, University of Gothenburg, SE-405 30

Göteborg, Sweden

Full list of author information is available at the end of the article
}

recently, big industrial players have launched free floating services in many cities around the world, where a car can be left anywhere within a given service area. These new developments have made car sharing more popular and encourages promising changes in transport systems [36, 51, 57].

Research on car sharing has shown that these services can function as an alternative for sustainable transportation [30, 44]. Car sharing may potentially have a substitute function for private car driving and complement public transportation, as long as some conditions are met [12]. Furthermore, it was found to have a positive correlation with an increase of active travel, such as cycling and walking [37]. By reducing $\mathrm{CO} 2$ emissions [25], private car use and demand for parking areas, car sharing has the potential to offer a sustainable solution that covers environmental and societal issues in dense urban areas.

However, the studies regarding car sharing use have mainly investigated specific populations in dense urban areas with no control for self-selection bias [46]. Looking at other studies, results show that the relation between travel behaviour change and car sharing use may not be as straightforward as claimed. For instance, the reduction of car ownership is more dependent on sociodemographic 
characteristics than on car sharing usage [38] and it depends on which kind of car sharing service is used [47].

Regarding the societal issues in dense urban areas, traffic congestion has been identified as a negative factor impacting people's perceptions of well-being [9] and having negative carry-over effects due to travel dissatisfaction [22, 26].

It is also important to point out that car sharing services may not be a solution for traffic congestion, and that they may even be contributing to it by reducing the demand for public transportation. Previous research has identified that the use of car sharing may reduce the demand for public transportation to some extent [43] and under certain time periods in which public transport services are not efficient enough [16]. There is also evidence that users of some segments of car sharing have a higher preference for car availability within car sharing services rather than a demand for other services (e.g. public transport accessibility) [28].

There are many studies on car sharing, many of which focus only on objective data such as Geographic Information System (GIS) analyses [24], sociodemographic information [52] and car ownership in the household [14]. However, few studies have investigated the psychological aspects related to travel behaviour and car sharing use [56].

The psychological research on transport has a long history and its diversity of contributions is evidence of a wellestablished research area $[13,27,59]$. Among the main contributions, the Theory of Planned Behaviour (TPB) along with the constructs of habits [64], environmental concern [49], norms [40] and values [41] have helped to understand the complex domain of travel behaviour.

The TPB postulates that behaviour can be predicted by intentions which are themselves in turn predicted by attitudes, social norms and perceived behaviour control [1]. This model has been largely used and successfully adapted in many studies to investigate travel behaviour $[19,39]$.

An important characteristic of travel behaviour is its repetitiveness, especially when it comes to commuting behaviour. As habits become stronger through the repetition of the behaviour under similar circumstances, intentions will be less predictive of the behaviour. Individuals with strong habits tend to consider fewer alternative transport options. Following this rationale, habit becomes a strong predictor of transport mode choice if the circumstances are stable $[6,7,63]$.

Psychological variables have been used as a means to segment a population regarding attitudinal and behavioural aspects of transportation. Previous studies have found that those segmentations provide valuable information for addressing the context-dependency of travel decision making [53], to map mobility cultures across countries $[17,32]$ and to investigate future mode choices alternative to the private car $[4,50]$.
This study proposes to give an holistic contribution for the research in transportation, which includes an overview of the relevant studies in transport behaviour research, the measurement of psychological variables along with sociodemographic variables to characterize segments of users and non-users of car sharing, and a discussion about the impact of car sharing services to sustainability and its relevance to transport research.

Based on a robust theoretical background, this study was formulated in order to fill some gaps in the literature. Firstly, car sharing services have not been taken into account as a characterisation of mobility styles in such a broad scope, including psychological and behavioural aspects with data collection across different cities. Secondly, many studies do not have a control group for comparison.

The first gap is filled through the inclusion of car sharing within the transport scenario for cluster characterisation based on behavioural, psychological and sociodemographic variables. The behavioural aspects investigated are the patterns of transportation for daily trips and the habit to choose the private car as the mode of transportation for different trip purposes. The psychological aspects investigated are people's attitudes towards car sharing, their environmental concern, personal norms towards the environment, their political orientation and more specifically their political considerations towards the environment, and the motives that they consider important when deciding to use car sharing services. Regarding the second gap, a control group was added to make more valuable comparisons of possible differences between users and non-users of car sharing.

This study included larger and smaller urban areas, covering mostly Italian $(N=17)$ and Swedish $(N=3)$ cities (96\% of the sample). In order to identify the facilitators and barriers to car sharing services, psychological, social and behavioural aspects involved in decision making relating to car sharing use were investigated.

The focus of the present paper is to answer the following four research questions:

R 1 - What are the profiles of both users and non-users of car sharing in European cities regarding their travel patterns and psychological aspects (e.g. attitudes, acceptability of car sharing, personal norms, environmental concern)?

R 2- How do they differ?

R 3 - Which motives are relevant for these groups when they consider using car sharing?

R 4 - Do users of car sharing travel more sustainably?

These questions are worth answering because with such information urban planners could address specific barriers for different segments of the population to 
travel more sustainably. Moreover, the solutions could be elaborated considering the transport patterns and demands that different segments of society have, and thus promote better mobility governance.

In the following sections, the survey methodology is described, as is the sampling across European cities. In the results section a cluster analysis is presented and the resulting mobility styles are described for both users and non-users of car sharing. The last section includes a critical discussion on the implications of these results for different stakeholders through a holistic perspective of sustainability.

\section{Method}

\subsection{Instrument and procedures}

Seven online versions of the questionnaire were distributed to respondents in Swedish, Italian, German, Dutch, Spanish, French and English languages, from April to June 2018. The Swedish questionnaire was distributed by the Laboratory of Opinion Research at the University of Gothenburg (LORE), targeting the cities of Stockholm, Gothenburg and Malmö. The Italian version of the questionnaire was first administered to a sample of non-users representative of the populations living in cities where at least one car sharing service was active at the time of the survey (namely Bari, Bologna, Brescia, Cagliari, Catania, Florence, Genova, Milan, Modena, Naples, Padova, Palermo, Parma, Rome, Turin, Venice and Verona). Additionally, car sharing users were targeted by distributing the questionnaire among the customers of two car sharing operators (BlueTorino and Enjoy). The administration of the survey was concentrated in those two countries. However, other countries (Germany, Belgium, Spain and France) were reached through social networks (e.g. the project's website, Twitter and LinkedIn) and through a convenience sample of organisations.

The participants had access to the questionnaire through a link. After having been provided with a definition of car sharing, the participants were asked if they are current users, previous users or non-users of any kind of car sharing service, including an option to select "I am not familiar with the concept of car sharing". The definition of car sharing stated in the survey was "Car sharing is a membership service available to all qualified drivers in a community. No separate written agreement is required each time a member reserves and uses a vehicle. The car sharing companies offer to their members the access to a dispersed network of shared vehicles 24hours, 7 days a week. It should be highlighted that the trips are not shared between drivers, only the vehicles are shared at different times by different drivers". The respondents that reported not being familiar with the concept of car sharing did not receive the specific questions regarding car sharing. The authors adopted this procedure in order to guarantee the validity of the responses and to avoid inducing respondents to answer questions about topics that they are not familiar with.

In the following sections of the questionnaire, 36 questions regarding attitudes towards car sharing, the environment, political orientation, personal norms, frequency of use of different transport modes and transport mode choice for different travel purposes were asked. Thus, the scales used for this analysis had items covering both attitudinal and behavioural aspects related to car sharing (see Table 1). Their items as well as how the indexes were computed for each scale are described below.

\subsubsection{Private car habit}

This measure, adapted from Verplanken et al. [62], consisted of one statement with the following instruction: "Below, some activities are listed. Which travel mode are you most likely to use to reach these activities?". An index was calculated using the sum of the frequency of choices for private car use in relation to other transport modes (car sharing, public transport, motorcycle, taxi, cycling, walking, other) for seven travel purposes: Visiting a close relative/friend, running an errand in the city centre, going out for dinner, making an excursion in pleasant weather, shopping for groceries, visiting a shopping centre and weekend activities.

\subsubsection{Transport for daily trips}

The main statement regarding this item was "If you think about your daily travels (to work, to study, for grocery shopping, etc.), how often do you use the following transport modes, on average?". Participants were asked to answer according to the following scale: (5) Daily; (4) 4-6 days/week; (3) 1-3 days/week; (2) Once/a few times a month; (1) More seldom; (0) Never. The frequency of use of eight transport modes for daily trips was measured: Private car as a driver, private car as a passenger, car sharing, public transport, motorcycle, taxi, cycling and walking. These measures were then grouped into three subgroups for later analyses: Private motorised daily trips (private car as a driver, private car as a passenger, car sharing, motorcycle/scooter and taxi), active daily trips (walking and cycling) and daily trips by public transport.

\subsubsection{Attitudes, environmental concern and personal norms scales}

These scales were adapted from a previous study on car use [39]. Attitudes to car sharing were measured through four items based on a 7-point Likert scale where $1=$ Very weak and $7=$ Very strong (e.g.: "My support for implementation of car sharing in society is ..." ). Environmental concern was measured through two items on a 7 -point Likert scale where $1=$ Strongly agree and $7=$ 


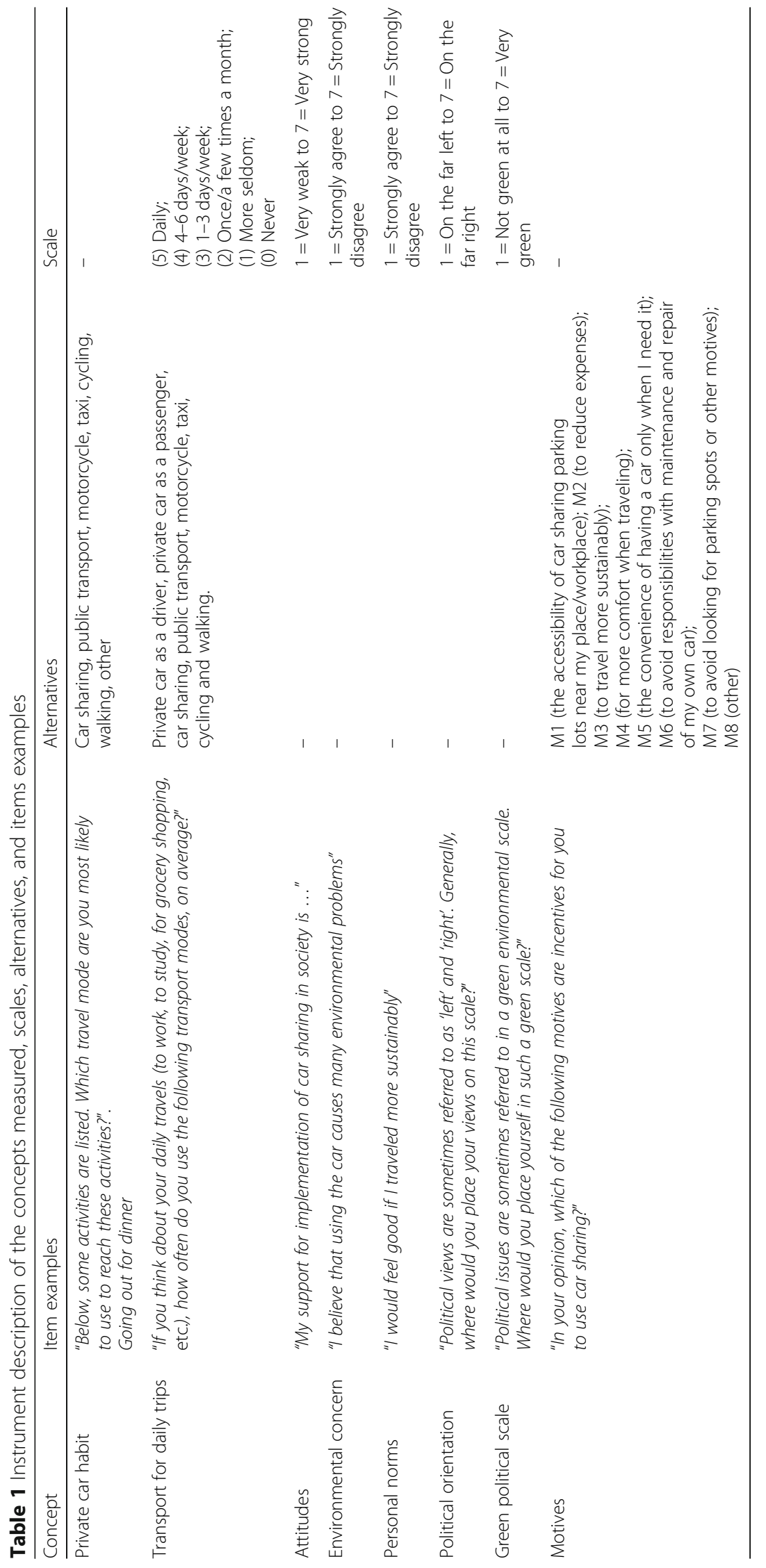


Strongly disagree (e.g.: "I believe that using the car causes many environmental problems"). Personal norms were measured through three items based on a 7-point Likert scale where $1=$ Strongly agree and $7=$ Strongly disagree (e.g.: "I would feel good if I traveled more sustainably").

\subsubsection{Political orientation}

Political orientation was measured by the item "Political views are sometimes referred to as 'left' and 'right'. Generally, where would you place your views on this scale?" with the answers based on a scale of 1 (= On the far left) to 7 (= On the far right).

\subsubsection{Green political scale}

Green political scale was measured by the item "Political issues are sometimes referred to in a green environmental scale. Where would you place yourself in such a green scale?" with the answers based on a scale of 1 (= Not green at all) to 7 (= Very green).

\subsubsection{Motives}

For the current users of car sharing, this concept was measured by the question "In your opinion, which of the following motives are incentives for you to use car sharing?". For the non-users of car sharing, the question was rephrased by "In your opinion, which of the following motives would be incentives for you to use car sharing?" The respondents could select more than one motive among eight alternatives: M1 (the accessibility of car sharing parking lots near my place/workplace); M2 (to reduce expenses); M3 (to travel more sustainably); M4 (for more comfort when traveling); M5 (the convenience of having a car only when I need it); M6 (to avoid responsibilities with maintenance and repair of my own car); M7 (to avoid looking for parking spots or other motives); and M8 (other).

\section{Results}

\subsection{Sample}

The sample comprised 1519 current users of car sharing and 3695 non-users. The mean age was between 40 and 49 years old, $50.7 \%$ were men, $48.8 \%$ had a personal monthly income before taxes up to $€ 2499$ and $70 \%$ of respondents had a college degree or higher levels of education. Regarding the household profile, $34.2 \%$ had two persons cohabiting, only $13.2 \%$ were car-free households and $50.7 \%$ owned one car. The nationalities were distributed among Italy (51.7\%), Sweden (44.5\%) and other countries $(3.8 \%)$. For a more detailed description of the sample, see Table 2. Given the unbalanced sampling across countries, the interpretation of the results was mainly focused on the differences between Italy and Sweden.

\subsection{Statistical analysis}

Among the different methods of cluster analysis, with different disciplines having its traditional approach to work with it, the selected method for this analysis was the popular method of agglomerative hierarchical cluster analysis, called the minimum variance method or Ward's method [67]. This method aims to maximise both between-group heterogeneity and within-group homogeneity [69] and it has been identified as the most accurate method if compared to other popular methods [11].

The Ward method agglomerates the elements of clustering by steps, following a metric and often generating a dendrogram for analysis of the distances between the elements. In each step, new elements are included in the cluster until an optimal number of clusters is achieved [21].

To form the clusters, this analysis identifies homogenous groups based on the criteria established by the researcher. The clustering variables in this research were private car preference, transport for daily trips (private motorised, active and public transport), attitudes, environmental concern, personal norms, political orientation and green political scale.

Cluster analysis can be classified as supervised and unsupervised methodologies. Supervised methodologies predefine the number of clusters a priori based on the researchers' set of rules. In unsupervised methodologies, free interaction among variables are allowed to determine the clusters and there is no a priori restriction on the number of clusters [2]. The second approach was used for the current analysis, with the number of clusters defined from the data. Two separate cluster analyses were conducted, one including only current car sharing users and a second analysis including only non-users. Three clusters emerged from the first analysis and two from the latter. The clusters are further described and named Mobility styles.

The indices of internal consistency for the above introduced three constructs of attitudes, environmental concern, and personal norms were satisfactory. The Cronbach's alphas were calculated to test the ability of the instrument to consistently measure the concepts. The alpha is also an estimate of the amount of the error in a test, varying from 0 to 1 (generally accepted as satisfactory from .7 to .95$)[15,61]$. Cronbach's alpha values for attitudes were .69 for current users and .71 for nonusers; Cronbach's alpha values for the environmental concern were .87 for current users and .91 for nonusers, and Cronbach's alpha values for the personal norms were .85 for current users and .88 for non-users.

\subsubsection{Cluster analysis for users}

The ratio size between the largest and smallest cluster was 2.45 and the measurement of cohesion and 
Table 2 Descriptive statistics of the sample by countries

\begin{tabular}{|c|c|c|c|c|c|c|}
\hline & \multicolumn{2}{|l|}{ Italy } & \multicolumn{2}{|l|}{ Sweden } & \multicolumn{2}{|l|}{ Others } \\
\hline & Users & Non-users & Users & Non-users & Users & Non-users \\
\hline Age (mean age) & $30-39$ & $40-49$ & $40-49$ & $40-49$ & $30-39$ & $30-39$ \\
\hline Gender (male) & $507(61.8 \%)$ & $947(50.6 \%)$ & $356(63.2 \%)$ & $1040(59.7 \%)$ & $83(63.8 \%)$ & $37(55.2 \%)$ \\
\hline Income $€$ (mean) & $2200-2499$ & 1800-2199 & $2850-3499$ & $2500-2849$ & $2500-2849$ & $2200-2499$ \\
\hline Education (university degree or more) & $596(72.5 \%)$ & $1009(53.8 \%)$ & $505(89.4 \%)$ & $1402(80 \%)$ & $35(66.1 \%)$ & $49(79 \%)$ \\
\hline Household (number of persons cohabiting) & 2 & 2 & 2 & 2 & 2 & 2 \\
\hline \multicolumn{7}{|l|}{ Car ownership } \\
\hline No car & $117(14.2 \%)$ & $89(4.8 \%)$ & $411(73.3 \%)$ & $431(25.4 \%)$ & $84(65.1 \%)$ & 19 (28.4\%) \\
\hline $1 \mathrm{car}$ & $363(44.2 \%)$ & 877 (46.8\%) & 110 (19.6\%) & $936(55.1 \%)$ & 36 (27.9\%) & 26 (38.8\%) \\
\hline 2 cars & 263 (32\%) & 757 (40.4\%) & 33 (5.9\%) & 277 (16.3\%) & 8 (6.2\%) & 17 (25.4\%) \\
\hline 3 or more & 79 (9.6\%) & $150(8 \%)$ & 7 (1.2\%) & $56(3.3 \%)$ & $1(.8 \%)$ & $5(7.5 \%)$ \\
\hline Total & 823 & 1874 & 565 & 1753 & 131 & 68 \\
\hline
\end{tabular}

separation was fair (average silhouette $=0.3$ ). The selected order of relevance of the variables to predict the clusters were: Environmental concern, private car preference, personal norms, green political scale, private motorised daily trips, political orientation, attitudes, active daily trips and daily trips by public transport.

\subsubsection{Cluster analysis for non-users}

The ratio size between the largest and smallest cluster was 1.31 and the measurement of cohesion and separation was fair (average silhouette $=0.3$ ). The selected order of relevance of the variables to predict the clusters were: Environmental concern, green political scale, personal norms, political orientation, attitudes, private car preference, daily trips by public transport, private motorised daily trips and active daily trips.

A description of each mobility style identified by the cluster analysis is reported below. It is important to note that the descriptions are relative to the values identified for the clusters and not to the absolute values of the scales (see Table 3).

\subsubsection{User mobility style 1}

Multi-mode and Low environmentalism (Multi-m Lenvironment) $(N=280,18.7 \%$ of users $)$. These car sharing users are characterised by a relatively medium level of private car habit. In general, they travel more seldom by private motorised modes: Once or a few times a month by a private car and car sharing. They use public transport or travel actively one to 3 days a week. They have the lowest level of environmental concern and personal norms. They would place themselves in a central-right political orientation, on a lower green political perspective and they have positive attitudes towards car sharing.

\subsubsection{User mobility style 2}

Car-focused Ambivalent (Car-f Amb) $(N=531,35.5 \%$ of users). These car sharing users have a relatively strong habit of private car use. They use a private car one to 3 days a week and only use public transport or travel actively once or a few times a month. Contrary to their strong private car habits, they have high environmental concern, strong personal norms to reduce the environmental impact of personal travel and have positive attitudes towards car sharing. They place themselves in the middle of a left-right political orientation and rate themselves as green in the political scale.

\subsubsection{User mobility style 3}

Active P-T transport Green (A P-T Green) $(N=685$, $45.8 \%$ of users). The car sharing users in this segment have the weakest habits of private car use and the lowest frequency of private motorised trips. Their daily travel routines mostly include active modes or public transportation. They have strong positive attitudes towards car sharing, high environmental concern and personal norms. They are more inclined towards a green political scale and a left wing political orientation.

\subsubsection{Non-user mobility style 4}

Car-focused Low-green (Car-f L-Green) (N=1574, $43.3 \%$ of non-users). This group has the strongest habits of private car use. They use a car for their daily travel one to three times a week, they make use of the public transportation more seldomly and once/a few times a month they travel actively. Their attitudes towards car sharing services are the lowest of all groups and they also have the second lowest environmental concern and the weakest personal norms. They would place themselves in a central-right political orientation and in a lower green political perspective. 
Table 3 Mean values (M) and standard deviations (SD) of clustering and complementary variables by mobility styles

\begin{tabular}{|c|c|c|c|c|c|}
\hline \multirow[t]{2}{*}{ Clustering variables } & \multicolumn{3}{|c|}{ Current users of car sharing } & \multicolumn{2}{|c|}{ Non-users of car sharing } \\
\hline & Mobility style 1 & Mobility style 2 & Mobility style 3 & Mobility style 4 & Mobility style 5 \\
\hline Private car habit M (SD) & $2.27(2.25)$ & $4.34(1.59)$ & $0.53(0.96)$ & $4.58(1.82)$ & $2.92(2.08)$ \\
\hline Private motorized daily trips M (SD) & $1.66(0.92)$ & $1.92(0.85)$ & $0.88(0.46)$ & $1.37(0.61)$ & $0.95(0.53)$ \\
\hline By private car (as a driver) & $2.30(1.70)$ & $3.13(1.64)$ & $0.73(0.93)$ & $3.37(1.68)$ & $2.05(1.74)$ \\
\hline By car sharing & $2.05(1.00)$ & $2.08(1.05)$ & $1.73(0.87)$ & - & - \\
\hline Active daily trips M (SD) & $3.11(1.14)$ & $2.68(1.10)$ & $3.64(1.00)$ & $2.18(1.13)$ & $2.88(1.05)$ \\
\hline Public transport daily trips M (SD) & $3.16(1.38)$ & $2.73(1.41)$ & $3.51(1.32)$ & $1.99(1.38)$ & $3.11(1.46)$ \\
\hline Attitudes M (SD) & $4.93(1.13)$ & $5.56(0.90)$ & $5.99(0.80)$ & $3.70(1.19)$ & $4.92(1.09)$ \\
\hline Environmental concern M (SD) & $3.59(1.47)$ & $6.17(0.89)$ & $6.36(0.65)$ & $4.16(1.64)$ & $6.41(0.80)$ \\
\hline Personal norms M (SD) & $3.02(1.26)$ & $5.70(1.03)$ & $5.62(1.40)$ & $3.46(1.53)$ & $5.38(1.50)$ \\
\hline Green political scale M (SD) & $3.83(1.37)$ & $5.57(1.08)$ & $5.88(1.00)$ & $3.89(1.50)$ & $5.63(1.10)$ \\
\hline Political orientation M (SD) & $4.64(1.43)$ & $3.53(1.35)$ & $2.95(1.30)$ & $4.48(1.35)$ & $2.99(1.35)$ \\
\hline \multicolumn{6}{|l|}{ Complementary variables } \\
\hline Monthly income up to $€ 3499$ (\%) & 53.7 & 62.4 & 52.0 & 58.0 & 66.9 \\
\hline College or higher educational level (\%) & 76.6 & 70.7 & 86.4 & 60.5 & 70.9 \\
\hline Single household (\%) & 21.1 & 12.1 & 26.9 & 17.0 & 21.2 \\
\hline Car-free household (\%) & 35.4 & 2.8 & 71.5 & 5.8 & 21.2 \\
\hline \multicolumn{6}{|l|}{ Nationalities (N(\%)) } \\
\hline Italy & $137(48.9)$ & $456(85.9)$ & $222(32.4)$ & $821(52.2)$ & $1051(51.1)$ \\
\hline Sweden & $132(47.1)$ & $65(12.2)$ & $357(52.1)$ & $742(47.1)$ & $952(46.3)$ \\
\hline Other countries & $11(1.7)$ & $10(1.9)$ & $106(15.6)$ & $11(0.8)$ & $55(2.6)$ \\
\hline
\end{tabular}

Motor based daily trips included measures of frequency of use of a private car as a driver, as a passenger, car sharing, motorcycles/scooters and taxis. For means of comparison, in the two lines below, the mean values (M) and standard deviations (SD) for private car as a driver and car sharing are reported. The statistics reported in nationalities represent the number of respondents per mobility style $(\mathrm{N})$ as well as the percentage that this amount represents within the mobility style (\%). Other countries include Germany, Belgium, France, Spain and other European countries

\subsubsection{Non-user mobility style 5}

Multi-mode and High environmentalism (Multi-m H-environment) ( $N=2058,56.7 \%$ of non-users). This group has a relatively medium level of private car use habits. Overall they have low frequencies of private motorised trips, they travel actively and by private car once/a few times a month and one to three times per week by public transport. They are positive to car sharing services, they have the highest environmental concern and strong personal norms to reduce the negative impact of their travels on the natural environment. Politically, they can be characterised as more green and as having a more left wing affiliation.

Motives M5 (the convenience of having a car only when I need it) and M6 (to avoid responsibilities with maintenance and repairs of my own car) were among the three motives most selected by all mobility styles. The motive M1 (the accessibility of car sharing pick up locations near my place/workplace) was among the three most selected for all mobility styles except for Mobility style 4, for which M2 (to reduce expenses) was the third most important motive. The least important motive among all mobility styles was M4 (for more comfort when traveling) (see Figs. 1 and 2).

\section{Discussions}

The results of this study successfully answered the research questions proposed. These aimed to identify the profiles of both users and non-users of car sharing (R1), to identify how those profiles differ (R2), to assess the main motives to use car sharing (R3) and to measure if car sharing users travel more sustainably (R4).

Through the cluster analysis, it was possible to identify five mobility styles based on their attitudinal, behavioural and political aspects, answering the first research question. The means indicating to what extent psychological aspects differ among the mobility styles of users and non-users of car sharing regarding their travel preferences were also shown by these results (see Table 1), addressing the second research question. In Figs 1 and 2, the motives to use car sharing are summarised to complement the descriptions of segments of mobility styles, addressing the third research question. The fourth research question was also answered by the clustering analysis. After identifying the five mobility styles, the users of car sharing, on average, did not present higher levels of use of public transportation or active travel modes, indicating that they do not necessarily travel more sustainably than the non-users. 


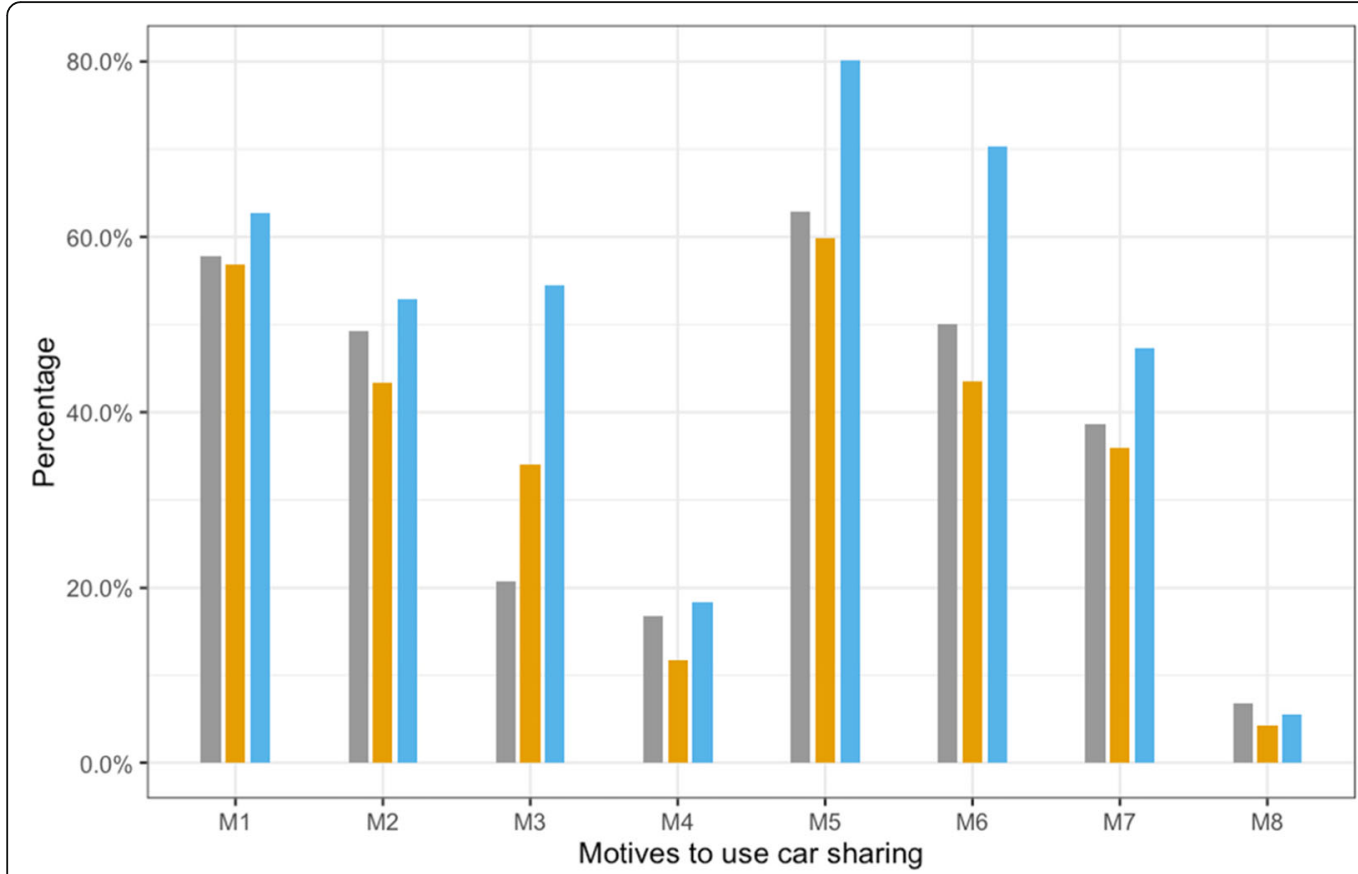

Fig. 1 Percentage of motives selected by user mobility styles, addressed by the question: In your opinion, which of the following motives are incentives for you to use car sharing? Note: M1 (the accessibility of car sharing parking lots near my place/workplace); M2 (to reduce expenses); M3 (to travel more sustainably); M4 (for more comfort when traveling); M5 (the convenience of having a car only when I need it); M6 (to avoid responsibilities with maintenance and repair of my own car); M7 (to avoid looking for parking spots or other motives); and M8 (other)

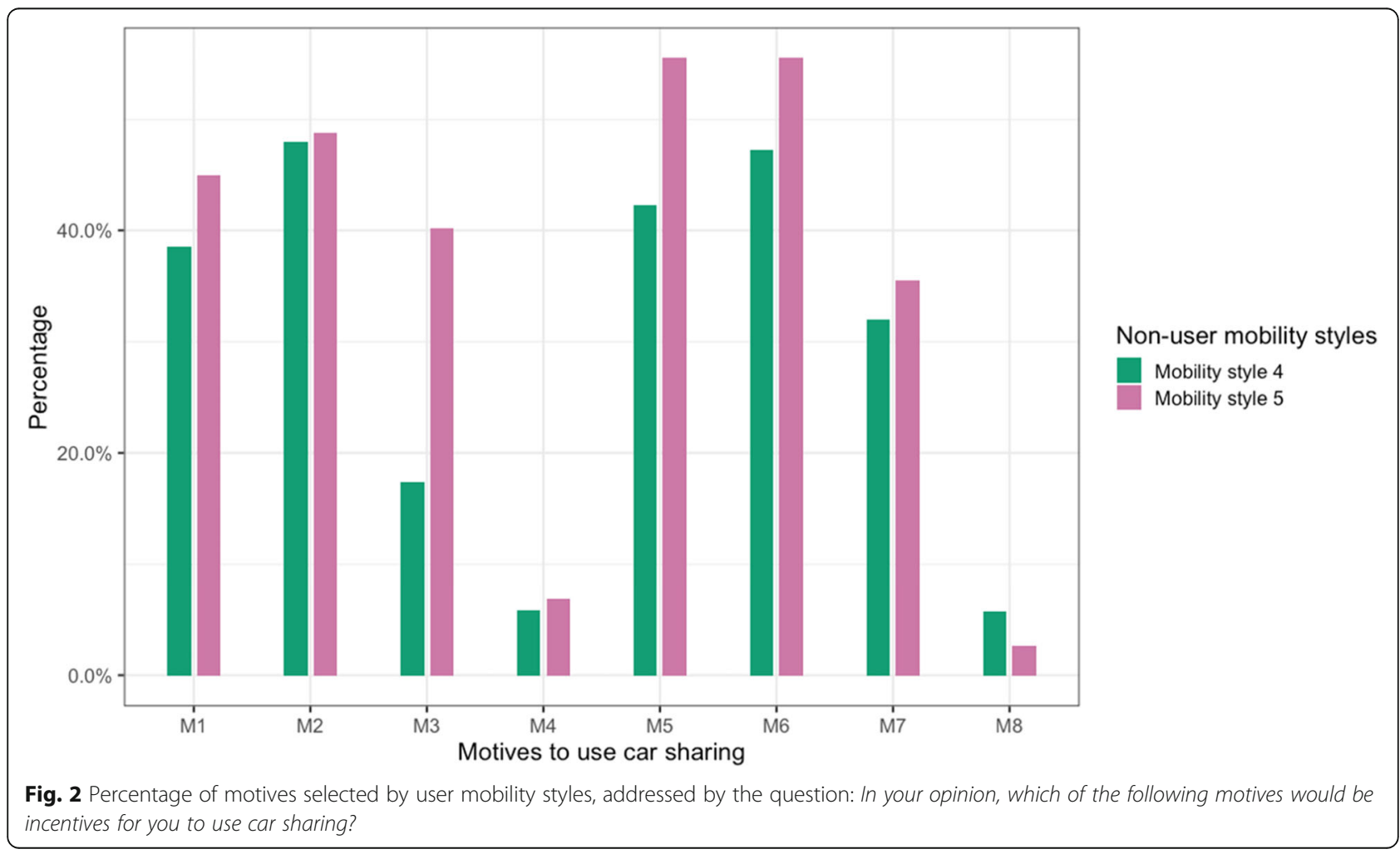


The main differences can be found between mobility styles 3 and 4. The User mobility style 3 are motivated to reduce the environmental impact of their personal travel choices, they have the highest percentage of carfree household and they have a low level of private car driving habit. All these considered, this mobility style could be seen as a target segment to be incentivised to grow even larger in the near future. This segment represents $45 \%$ of car sharing users in the sample and it is more common in Sweden, accounting for $52 \%$ of the users in this segment.

The segment with higher preference for private car use and least concern to environmental impacts of transportation is the Non-user mobility style 4 . This mobility style is not associated to a specific country and the individuals' motivation to use or possibly become a user of car sharing is unclear. The percentages of motives chosen were spread out, and the means for the use of public transport and attitudes towards car sharing were the lowest among segments. A likely prediction is that this group may be the most resistant to using car sharing services for their personal travels.

Differences between Italy and Sweden concerning the role of cars to satisfy mobility needs are likely to affect our results. Both car ownership rates [23] and the fraction of trips made by car [20] are higher in the 17 Italian cities where the survey was spread, compared to the three Swedish cities. In this perspective, car sharing users in Italy are embracing this new mobility alternative since they recognise that it includes the main advantages of a private car yet without the costs associated with ownership. High levels of pollution, particularly in the northern part of the country, represent an increasing environmental concern for citizens, especially since the entry into force of EU regulations related to air quality standards. The use of car sharing may, therefore, be seen as an alternative and a way to reduce the environmental impact of their travel choices. Indeed, on average, car sharing vehicles have a lower level of emissions of pollutants and greenhouse gases compared to the private car fleet [10].

However, the strong predominance of free-floating services in Italian cities creates a gap in the car sharing offer which restricts its current use to a set of limited scenarios, namely short and inner-city trips [31]. Thus, car sharing is not completely substituting the use of private cars, since it is not a convenient solution for longer trips. Longer trips are better suited to station-based services, which in turn are more flexible and attractive than traditional car rentals [58].

This study also aimed to make a contribution to a more complex question: Do users of car sharing travel more sustainably? In this respect, the cluster analysis included the measurements of private car habit and transport mode choice for daily trips, which are measures of the repetitiveness and automaticity, respectively, of choosing a certain mode of transport. These measurements can be interpreted as proxy variables to measure habitual travel behaviour [62]. By understanding the pattern of travel across mobility styles, one may identify which segments of users and non-users of car sharing have a more sustainable pattern of travels - actively travelling and less dependent on a private car [3].

What was identified is that car sharing users do not necessarily travel more sustainably or give up ownership of private cars. Except for User mobility style 3, the mean frequency of the use of a private car is roughly the same across mobility styles of users and non-users, and the percentage in which sustainability was selected as a motive to use car sharing was below 50\% (see Figs. 1 and 2).

These results give support for the argument that car sharing services by themselves may not be a long-term solution to promote more sustainable travels within cities. In a context of climate crisis, in which all efforts are demanded to keep the rise of Earth's temperature under $1.5^{\circ} \mathrm{C}$ [33], the transport sector should be focusing on effective solutions to reduce their contribution to climate change. Failing to accomplish with the IPCC report recommendations may imply risks for the longterm human and environmental security by depleting the natural resources [8].

There is empirical evidence that supports a relationship between beliefs in climate change and political orientation $[45,60]$. This relationship can be partially explained by the ideologies endorsed by some segments of society and political parties. For instance, some climate policies may be interpreted by right-leaning segments as threats to a free market and individual choice. These interpretations, biased by ideologies, have created a polarised politicisation of climate change perception [68].

Given this ideological background surrounding beliefs in climate change, the extent to which one is aware of its impact on the environment due to one's travel also influences the attitudes towards different modes of transportation. Moreover, believing in technological solutions and that the market will solve environmental issues is associated with lower levels of environmental concern $[29,66]$. However, an alternative to induce climate change deniers to behave more proenvironmentally is the use of communication framings that supports technological innovations to promote pro-environmental behaviour [5].

In this study, the mobility styles with more orientation towards a right-wing positioning were the User mobility style 1 and Non-user mobility style 4 . In line with the previously mentioned literature, these segments presented the lower levels of environmental concern, the lower personal norms to reduce their impact on the 
environment due to their travel patterns and they positioned themselves as less green when asked about political orientation.

The low level of behaviour change among users may be interpreted in two perspectives. The first interpretation is that most of the segments of travellers do not consider environmental issues when deciding on their mode of transport. Among the motives to use car sharing, sustainability was a relatively important motive only for the Users mobility style 3 and Non-users mobility style 5 .

The second interpretation is that people do not see car sharing as a more sustainable way of travelling because it is a service based on cars and therefore still maintains a certain level of pollution inherent to cars (eg. the life cycle of the production of cars and batteries, in the case of electric vehicles).

Previous research has identified that the environmental concern, which is central for the concept of sustainability, was a relevant predictor for behavioural intention to use car sharing in the near future [58]. However, this relationship was indirect. Through a Structural Equation Modelling (SEM) analysis, it was identified that environmental concern was a predictor of personal norms, which by itself predicted attitudes towards car sharing. Further investigations need to address this matter, in order to identify what are people's perceptions of car sharing regarding its environmental impact and in which extent they are motivated to change their travel behaviour due to sustainability issues.

This study has, however, some limitations. It doesn't control for which kind of car sharing service users are registered with (free floating, station based, etc); the sample is fairly highly educated if compared to the general population and is unbalanced across countries. Moreover, since it is a cross-sectional correlational design the interpretations of these results do not explain causal relations, and it does not control for possible cofounders and the precedence of independent variables in relation to the dependent variables.

\section{Conclusions}

The five segments of users and non-users of car sharing shows how those groups of society differs regarding psychological and behavioural aspects. This kind of segmentation is a valuable source of knowledge for tailored communications efforts. By working with an audience segmentation, climate change communicators may develop framings that increase the salience of the message for each group and therefore be more persuasive [42].

On the one hand, communication messages for users with high levels of private car driving habit could frame car sharing as an alternative to give support for the decision to refrain from buying a car in the future or that that car sharing could be a substitute of a second or third car [48].

On the other hand, for the segments with high levels of personal norms to reduce the environmental impact connected to their travel choices, such as the segment of User mobility style 3, the messages should be framed in line with their motivational drivers and their attitudes. The messages for this segment would mostly benefit by making salient the positive impacts in the environment if giving up using a private car. Moreover, the message could be even more efficient if connected with the facilities characterized as the main motives to use car sharing, such as the convenience of having a car only when it is needed and avoiding the maintenance responsibilities of a private car.

Based on the evidence from this study, it is not possible to confirm whether car sharing services promote more sustainable patterns of transportation among users. Policy makers, diplomatic organisations and researchers should critically evaluate how policy formation and decision-making regarding car sharing are formed in a way that guarantee the implementation of socially robust technologies that would most benefit the society and the natural environment [65].

Therefore, it is necessary to continue the investigation of the environmental impact of car sharing services and in which ways these services are affecting people's travel behaviour. Future research should also take into account the psychological barriers of behavioural change, such as habits. Habits play an important role and can in different levels affect different kinds of travel behaviours [54]. Furthermore, people may not be willing to change old habits even when alternative services are in place [34].

Another important aspect for future investigation is the impact that subscribing to a car sharing service has on the travel patterns. Moreover, it is important to further identify differences in the behaviour given the kind of car sharing service that people have subscribed to, such as peer-to-peer, free-floating and station-based car sharing services. Therefore, future research would benefit from studies that measure people's travel patterns before and after registering to different services to account for temporal precedence of events and to go beyond correlational analysis.

\section{Acknowledgements}

Acknowledgements to all partners of the European project "Shared mobility opporTunities And challenges foR European citieS" (STARS) (Horizon 2020,

grant number 769513).

Your sincerely,

Érika Martins Silva Ramos

Corresponding author

Authors' contributions

All authors, ÉMSR, CJB, AC and MD contributed to the concept and design of the work, to the acquisition of data and data analysis, and to the

interpretation of data. All authors read and approved the final manuscript. 


\section{Funding}

This study was funded by Horizon 2020 (grant number 769513) under the European project "Shared mobility opporTunities And challenges foR European citieS" (STARS). Open access funding provided by University of Gothenburg.

\section{Availability of data and materials}

The datasets used and/or analysed during the current study are available from the corresponding author on reasonable request. From August 2019, the datasets will be available at the platform Zenodo with embargoed access until publication.

\section{Competing interests}

The authors declare that they have no competing interests.

\section{Author details}

'Department of Psychology Box 500, University of Gothenburg, SE-405 30 Göteborg, Sweden. ${ }^{2}$ Department of Environment, Land and Infrastructure Engineering Corso Duca degli Abruzzi 24, Politecnico di Torino, 10129 Turin, Italy.

\section{Received: 8 July 2019 Accepted: 4 February 2020}

\section{Published online: 02 March 2020}

\section{References}

1. Ajzen, I. (1991). The theory of planned behavior. Orgnizational Behavior and Human Decision Processes, 50, 179-211. https://doi.org/10.1016/07495978(91)90020-T.

2. Almeida, J. A. S., Barbosa, L. M. S., Pais, A. A. C. C., \& Formosinho, S. J. (2007). Improving hierarchical cluster analysis: A new method with outlier detection and automatic clustering. Chemometrics and Intelligent Laboratory Systems, 87(2), 208-217. https://doi.org/10.1016/j.chemolab.2007.01.005.

3. Anable, J. (2005). 'Complacent Car Addicts' or 'Aspiring Environmentalists'? Identifying travel behaviour segments using attitude theory. Transport Policy, 12(1), 65-78. https://doi.org/10.1016/j.tranpol.2004.11.004

4. Anable, J., \& Gatersleben, B. (2005). All work and no play? The role of instrumental and affective factors in work and leisure journeys by different travel modes. Transportation Research Part A: Policy and Practice, 39(2-3 SPEC. ISS), 163-181. https://doi.org/10.1016/j.tra.2004.09.008.

5. Bain, P. G., Hornsey, M. J., Bongiorno, R., \& Jeffries, C. (2012). Promoting proenvironmental action in climate change deniers. Nature Climate Change, 2(8), 603-603. https://doi.org/10.1038/nclimate1636.

6. Bamberg, S., Ajzen, I., \& Schmidt, P. (2003). Choice of Travel Mode in the Theory of Planned Behavior: The Roles of Past Behavior, Habit, and Reasoned Action. Basic and Applied Social Psychology, 25(3), 175-187. https://doi.org/10.1207/S15324834BASP2503_01.

7. Bamberg, S., \& Schmidt, P. (2010). Choice of Travel Mode in the Theory of Planned Behavior : The Roles of Past Behavior. Habit, and Reasoned Action, 3533(October 2013), 37-41. https://doi.org/10.1207/S15324834BASP2503.

8. Bendell, J. (2018). Deep Adaptation: A map for navigating climate tragedy. IFLAS Occasional Paper, 2, 1-31 https://www.lifeworth.com/deepadaptation.pdf.

9. Bergstad, C. J., Gamble, A., Hagman, O., Polk, M., Gärling, T., \& Olsson, L. E. (2011). Affective - symbolic and instrumental - independence psychological motives mediating effects of socio-demographic variables on daily car use. Journal of Transport Geography, 19(1), 33-38. https://doi.org/10. 1016/j.jtrangeo.2009.11.006

10. Biedanelli, P. (2018). CAR SHARING IN ITALIA : LE OPPORTUNITÀ PER LO SVILUPPO DEI SERVIZI. Retrieved March 14, 2018, from: http://www. muoversincitta.it/wp-content/uploads/2018/03/Car-sharing-in-Italia-leopportunit\%C3\%A0-per-lo-sviluppo-dei-servizi.pdf

11. Blashfield, R. K. (1976). Mixture model tests of cluster analysis: Accuracy of four agglomerative hierarchical methods. Psychological Bulletin, 83(3), 377388. https://doi.org/10.1037/0033-2909.83.3.377.

12. Ceccato, R., \& Diana, M. (2018). Substitution and complementarity patterns between traditional transport means and car sharing: a person and trip level analysis. Transportation, 0123456789, 1-18. https://doi.org/10.1007/ s11116-018-9901-8

13. Chng, S., Abraham, C., White, M. P., Hoffmann, C., \& Skippon, S. (2018) Psychological theories of car use: An integrative review and conceptual framework. Journal of Environmental Psychology, 55, 23-33. https://doi.org/ 10.1016/j.jenvp.2017.10.009.
14. Clewlow, R. R. (2016). Carsharing and sustainable travel behavior: Results from the San Francisco Bay Area. Transport Policy, 51(2016), 158-164. https://doi.org/10.1016/j.tranpol.2016.01.013.

15. Cronbach, L. J. (1951). Coefficient alpha and the internal structure of tests. Psychometrika, 16(3), 297-334. https://doi.org/10.1007/BF02310555.

16. de Luca, S., \& Di Pace, R. (2015). Modelling users' behaviour in inter-urban carsharing program: A stated preference approach. Transportation Research Part A: Policy and Practice, 71, 59-76. https://doi.org/10.1016/j.tra.2014.11.001.

17. Diana, M., \& Mokhtarian, P. L. (2009). Grouping travelers on the basis of their different car and transit levels of use. Transportation, 36(4), 455-467. https://doi.org/10.1007/s11116-009-9207-y.

18. Docherty, I., Marsden, G., \& Anable, J. (2018). The governance of smart mobility. Transportation Research Part A: Policy and Practice, 115, 114-125. https://doi.org/10.1016/j.tra.2017.09.012.

19. Donald, I. J., Cooper, S. R., \& Conchie, S. M. (2014). An extended theory of planned behaviour model of the psychological factors affecting commuters' transport mode use. Journal of Environmental Psychology, 40, 39-48. https://doi.org/10.1016/j.jenvp.2014.03.003.

20. EPOMM, 2019, TEMS - The EPOMM Modal Split Tool, http://www.epomm. eu/tems/index.phtml

21. Eszergár-Kiss, D., \& Caesar, B. (2017). Definition of user groups applying Ward's method. Transportation Research Procedia, 22, 25-34. https://doi.org/ 10.1016/j.trpro.2017.03.004

22. Ettema, D., Gärling, T., Olsson, L. E., Friman, M., \& Moerdijk, S. (2013). The road to happiness: Measuring Dutch car drivers' satisfaction with travel. Transport Policy, 27, 171-178. https://doi.org/10.1016/j.tranpol.2012.12.006.

23. EU (2019). EU transport in figures - Statistical pocketbook 2019, https://ec europa.eu/transport/facts-fundings/statistics/pocketbook-2019_en

24. Ferrero, F., Perboli, G., Rosano, M., \& Vesco, A. (2018). Car-sharing services: An annotated review. Sustainable Cities and Society, 37(October 2017), 501-518. https://doi.org/10.1016/j.scs.2017.09.020.

25. Firnkorn, J., \& Muller, M. (2015). Free-floating electric carsharing-fleets in smart cities: The dawning of a post-private car era in urban environments? Environmental Science \& Policy, 45, 30-40. https://doi.org/10.1016/j.envsci.2014.09.005.

26. Friman, M., Gärling, T., Ettema, D., \& Olsson, L. E. (2017). How does travel affect emotional well-being and life satisfaction? Transportation Research Part A: Policy and Practice, 106(June 2016), 170-180. https://doi.org/10.1016/j. tra.2017.09.024.

27. Gardner, B., \& Abraham, C. (2008). Psychological correlates of car use: A meta-analysis. Transportation Research Part F: Traffic Psychology and Behaviour, 11(4), 300-311. https://doi.org/10.1016/j.trf.2008.01.004.

28. Giesel, F., \& Nobis, C. (2016). The Impact of Carsharing on Car Ownership in German Cities. Transportation Research Procedia, 19(June), 215-224. https://doi.org/10.1016/j.trpro.2016.12.082.

29. Gifford, R., \& Nilsson, A. (2014). Personal and social factors that influence pro-environmental concern and behaviour: A review. International Journal of Psychology, 49(3), n/a-n/a. doi: https://doi.org/10.1002/ijop.12034

30. Goldman, T., \& Gorham, R. (2006). Sustainable urban transport: Four innovative directions. Technology in Society, 28(1-2), 261-273. https://doi. org/10.1016/j.techsoc.2005.10.007

31. Habibi, S., Voronov, A., Engdahl, H., Wedlin, J., Englund, C., Sprei, F., \& Petterson, S. (2017). Comparison of free-floating car sharing services in cities. European Council of Energy Efficient Economy (ECEEE) Summer Study, Presqu'île de Giens, France, 29 May-3 June, 2017, 771-778.

32. Haustein, S., \& Nielsen, T. A. S. (2016). European mobility cultures: A survey-based cluster analysis across 28 European countries. Journal of Transport Geography, 54, 173-180. https://doi.org/10.1016/j.jtrangeo. 2016.05.014.

33. IPCC (2018). Summary for Policymakers. In: Global warming of $1.5^{\circ} \mathrm{C}$. An IPCC Special Report on the impactsof global warming of $1.5^{\circ} \mathrm{C}$ above preindustrial levels and related global greenhouse gas emission pathways, in the context of strengthening the global response to the threat of climate change, sustainable development, and efforts to eradicate poverty [V. Masson-Delmotte, P. Zhai, H. O. Pörtner, D. Roberts, J. Skea, P. R. Shukla, A. Pirani, W. Moufouma-Okia, C. Péan, R. Pidcock, S. Connors, J. B. R. Matthews, Y. Chen, X. Zhou, M. I. Gomis, E. Lonnoy, T. Maycock, M. Tignor, T. Waterfield (eds.)]. World Meteorological Organization, Geneva 32

34. Itzchakov, G., Uziel, L., \& Wood, W. (2018). When attitudes and habits don 't correspond: Self-control depletion increases persuasion but not behavior. Journal of Experimental Social Psychology, 75, 1-10. https://doi.org/10.1016/j. jesp.2017.10.011. 
35. Kates, R. W., Parris, T. M., \& Leiserowitz, A. A. (2005). What is sustainable development? Goals, indicators, values, and practice. Environment, 47(3), 8-21. https://doi.org/10.1080/00139157.2005.10524444.

36. Katzev, R. (2003). Car Sharing: A New Approach to Urban Transportation Problems. Analyses of Social Issues and Public Policy, 3(1), 65-86. https://doi org/10.1111/j.1530-2415.2003.00015.x.

37. Kent, J. L. (2014). Carsharing as active transport: What are the potentia health benefits? Journal of Transport \& Health, 1(1), 54-62. https://doi.org/ 10.1016/j.jth.2013.07.003

38. Kim, D., Ko, J., \& Park, Y. (2015). Factors affecting electric vehicle sharing program participants' attitudes about car ownership and program participation. Transportation Research Part D: Transport and Environment, 36, 96-106. https://doi.org/10.1016/j.trd.2015.02.009.

39. Klöckner, C. A., \& Friedrichsmeier, T. (2011). A multi-level approach to travel mode choice - How person characteristics and situation specific aspects determine car use in a student sample. Transportation Research Part F: Traffic Psychology and Behaviour, 14(4), 261-277. https://doi.org/10.1016/j.trf.2011.01.006.

40. Kormos, C., Gifford, R., \& Brown, E. (2015). The Influence of Descriptive Social Norm Information on Sustainable Transportation Behavior. Environment and Behavior, 47(5), 479-501. https://doi.org/10.1177/0013916513520416.

41. Lind, H. B., Nordfjærn, T., Jørgensen, S. H., \& Rundmo, T. (2015). The valuebelief-norm theory, personal norms and sustainable travel mode choice in urban areas. Journal of Environmental Psychology, 44, 119-125. https://doi. org/10.1016/j.jenvp.2015.06.001.

42. Markowitz, E. M., \& Guckian, M. L. (2018). Climate change communication: Challenges, insights, and opportunities. In S. Clayton \& C. Manning (Eds.), Psychology and Climate Change: Human perceptions, impacts, and responses (pp. 35-63). Elsevier. https://doi.org/10.1016/B978-0-12-813130-5.00003-5.

43. Martin, E., \& Shaheen, S. (2011). The impact of carsharing on public transit and non-motorized travel: An exploration of North American carsharing survey data. Energies, 4(11), 2094-2114. https://doi.org/10.3390/en4112094.

44. Meijkamp, R. (1998). Changing consumer behaviour through eco-efficient services: an empirical study of car sharing in the Netherlands. Business Strategy and the Environment, 7(4), 234-244 https://doi.org/10.1002/ (SICI) 1099-0836(199809)7:4<234::AID-BSE159>3.0.CO;2-A.

45. McCright, A. M., \& Dunlap, R. E. (2011). The Politicization of Climate Change and Polarization in the American Public's Views of Global Warming, 20012010. The Sociological Quarterly, 52(2), 155-194. https://doi.org/10.1111/j. 1533-8525.2011.01198.x.

46. Mishra, G. S., Clewlow, R. R., Mokhtarian, P. L., \& Widaman, K. F. (2015). The effect of carsharing on vehicle holdings and travel behavior: A propensity score and causal mediation analysis of the San Francisco Bay Area. Research in Transportation Economics, 52, 46-55. https://doi.org/10.1016/j.retrec.2015.10.010.

47. Namazu, M., Zhao, J., \& Dowlatabadi, H. (2018). Nudging for responsible carsharing: using behavioral economics to change transportation behavior. Transportation, 45(1), 105-119. https://doi.org/10.1007/s11116-016-9727-1.

48. Nijland, H., \& van Meerkerk, J. (2017). Mobility and environmental impacts of car sharing in the Netherlands. Environmental Innovation and Societal Transitions, 23, 84-91. https://doi.org/10.1016/j.eist.2017.02.001.

49. Nordlund, A. M., \& Garvill, J. (2003). Effects of values, problem awareness, and personal norm on willingness to reduce personal car use. Journal of Environmental Psychology, 23(4), 339-347. https://doi.org/10.1016/S02724944(03)00037-9.

50. Plazier, P. A., Weitkamp, G., \& Van Den Berg, A. E. (2018). Exploring the Adoption of E-Bikes by Different User Groups. Frontiers in Built Environment, 4, 47. https://doi.org/10.3389/fbuil.2018.00047.

51. Prettenthaler, F. E., \& Steininger, K. W. (1999). From ownership to service use lifestyle: The potential of car sharing. Ecological Economics, 28(3), 443-453. https://doi.org/10.1016/S0921-8009(98)00109-8.

52. Prieto, M., Baltas, G., \& Stan, V. (2017). Car sharing adoption intention in urban areas: What are the key sociodemographic drivers? Transportation Research Part A: Policy and Practice, 101, 218-227. https://doi.org/10.1016/j. tra.2017.05.012.

53. Prillwitz, J., \& Barr, S. (2011). Moving towards sustainability? Mobility styles, attitudes and individual travel behaviour. Journal of Transport Geography, 19(6), 1590-1600. https://doi.org/10.1016/j.jtrangeo.2011.06.011.

54. Ramos, É. M. S., Bergstad, C. J., \& Nässén, J. (2019). Understanding daily car use: Driving habits, motives, attitudes, and norms across trip purposes. Transportation Research Part F: Traffic Psychology and Behaviour. https://doi.org/10.1016/j.trf.2019.11.013.
55. Sachs, J. (2015). The age of sustainable development. New York: Columbia University Press.

56. Schaefers, T. (2013). Exploring carsharing usage motives: A hierarchical means-end chain analysis. Transportation Research Part A: Policy and Practice, 47, 69-77. https://doi.org/10.1016/j.tra.2012.10.024.

57. Sprei, F. (2017). Disrupting mobility. Energy Research \& Social Science, 1-5. https://doi.org/10.1016/j.erss.2017.10.029.

58. STARS. (2018). The influence of socioeconomic factors in the diffusion of car sharing. Retrieved from http://stars-h2020.eu/about-stars-deliverables/ \#behavioural_change_determinants_

59. Steg, L. (2007). SUSTAINABLE TRANSPORTATION. IATSS Research, 31(2), 58-66. https://doi.org/10.1016/S0386-1112(14)60223-5.

60. Straughan, R. D., \& Roberts, J. A. (1999). Environmental segmentation alternatives: a look at green consumer behavior in the new millennium. Journal of Consumer Marketing, 16(6), 558-575. https:/doi.org/10.1108/07363769910297506.

61. Tavakol, M., \& Dennick, R. (2011). Making sense of Cronbach's alpha. International Journal of Medical Education, 2, 53-55. https://doi.org/10.5116/ ijme.4dfb.8dfd.

62. Verplanken, B., Aarts, H., \& Van Knippenberg, A. (1994). Attitude Versus General Habit : Antecedents of Travel Mode Choice. Journal of Applied Social Psychology, 24(4), 285-300.

63. Verplanken, B., Aarts, H., \& Van Knippenberg, A. (1997). Habit, information acquisition, and the process of making travel mode choices. European Journal of Social Psychology, 27, 539-560. https://doi.org/10.1002/(sici)10990992(199709/10)27:5<539::aid-ejsp831>3.3.co;2-1.

64. Verplanken, B., \& Orbell, S. (2003). Reflections on Past Behavior : A SelfReport Index of Habit Strength. Journal of Applied Social Psychology, 33(6), 1313-1330.

65. Vlek, C. (2000). Essential psychology for environmental policy making. International Journal of Psychology, 35(2), 153-167. https://doi.org/10.1080/ 002075900399457.

66. Von Borgstede, C., Andersson, M., \& Johnsson, F. (2013). Public attitudes to climate change and carbon mitigation-Implications for energy-associated behaviours. Energy Policy, 57, 182-193. https://doi.org/10.1016/j.enpol.2013.01.051.

67. Ward, J. H. (1963). Hierarchical Grouping to Optimize an Objective Function. Journal of the American Statistical Association, 58(301), 236-244 Retrieved from https://www.jstor.org/stable/2282967.

68. Whitmarsh, L., \& Capstick, S. (2018). Perceptions of climate change. In S. Clayton \& C. Manning (Eds.), Psychology and Climate Change (pp. 13-33). Elsevier. https://doi.org/10.1016/B978-0-12-813130-5.00002-3.

69. Yim, O., \& Ramdeen, K. T. (2015). Hierarchical Cluster Analysis : Comparison of Three Linkage Measures and Application to Psychological Data. The Quantitative Methods for Psychology, 11(1), 8-21.

\section{Publisher's Note}

Springer Nature remains neutral with regard to jurisdictional claims in published maps and institutional affiliations.

\section{Submit your manuscript to a SpringerOpen ${ }^{\bullet}$ journal and benefit from:}

- Convenient online submission

- Rigorous peer review

- Open access: articles freely available online

- High visibility within the field

- Retaining the copyright to your article

Submit your next manuscript at $>$ springeropen.com 